\title{
Penggunaan Alang-alang untuk Mengendalikan Gulma dan Meningkatkan Produksi Tanaman Jagung (Zea mays L.) di Lahan Kering
}

\author{
Idi Darpan Maulana dan M. A. Chodzin \\ Departemen Agronomi dan Hortikultura, Fakultas Pertanian, Institut Pertanian Bogor, Jl \\ Meranti, Kampus IPB Darmaga, Bogor 16680 \\ E-mail : idi.darpan@yahoo.com
}

\begin{abstract}
A field experience conducted at Cikabayan, IPB Dramaga Bogor from January to Juni 2010 was designed to determine the effect of different dosage of 'alang-alang' much compared with control such as nno weeding and usual weeding on growth and yield of corn. The experiment was designed in a randomized complete block designed with three replications. The treatment was dosage of 'alang-alang' mulch consisting of 0, 2, 4, 6, 8 ton ha ${ }^{-1}$. Result indicated thar 'alang-alang' mulching ( 6 and 8 ton ha ${ }^{-1}$ ) increased plant growth and production. Beside that, 'alang-alang' mulching suppressed weed growth.

Keywords : alang-alang, mulch, weed, maize
\end{abstract}

\section{PENDAHULUAN}

Jagung merupakan tanaman pangan dari jenis rumput yang dibudidayakan paling luas di Indonesia setelah padi. Daerah sentra produksinya meliputi Jawa Timur, Jawa Tengah, Lampung, Sumatera Utara, Sulawesi Selatan dan gorontalo. Produksi nasional pada tahun 2009 sebesar 17.59 juta ton dengan produktivitas 4.32 ton/ha (Kementerian Pertanian, 2011). Produksi ini masih bisa ditingkatkan diantaranya dengan memperluas areal produksi dan atau meningkatkan produktivitas.

Perluasan lahan dapat diarahkan ke lahan kering, arena lahan kering di Indonesia masih belum dimanfaatkan secara maksimal. Pada tahun 2005, Jawa Barat memiliki lahan kering seluas 3.214 .484 ha yang produktivitasnya masih rendah (Departemen Pertanian, 2009). Hal ini disebabkan lahan kering memiliki beberapa kendala. Menurut As-syakur (2007), kendala yang dihadapi pada lahan kering yaitu kekeringan pada musim kemarau, kekurangan unsure hara dan erosi ditambah juga dengan permasalahan gulma.

Salah satu cara meningkatkan produksi pertanian yaitu dengan cara memanipulasi lingkungan tumbuh tanaman. Upaya memanipulasi lingkungan yang dapat dilakukan yaitu dengan pemulsaan. Mulsa merupakan material yang di atas permukaan tanah. Pemberian mulsa dapat secara langsung berpengaruh terhadap lingkungan tumbuh tanaman seperti mencegah erosi, serta meningkatkan kadar air tanah, suhu tanah, udara tanah dan refleksi sinar matahari (Umboh, 2000).

Pemberian mulsa dapat meningkatkan hasil tanaman budidaya. Pemberian mulsa alang-alang sebanyak 6 ton/ha meningkatkan jumlah polong per tanaman, jumlah polong isi dan berat kering biji per petak tanaman kacang kedelai (Fahrurrozi et. al., 2005). Pada tanaman kentang pemberian mulsa dapat meningkatkan laju pertumbuhan relative dan produksi umbi. Hal ini dikarenakan pemberian mulsa dapat menekan pertumbuhan gulma sehingga tanaman tidak berkompetensi untuk memanfaatkan sinar matahari dan menyerap unsure hara (Umboh, 2000).

Pemberian mulsa juga dapat menyuburkan tanah. Mulsa dapat menjaga kestabilan agregat dan kimia tanah, menjaga ketersediaan air tanah dan menjaga suhu 
tanah, meningkatkan ketersediaan unsure $\mathrm{K}$ dalam tanah dan mencegah pencucian nitrogen (Fahrurrozi et. al., 2005; Umboh, 2000 dan Sudadi et. al, 2007).

Tujuan lain pemulsaan adalah untuk pengendalian gulma. Menurut Sukma dan Yakup (2002), gulma perlu dikendalikan karena (1) menurunkan produksi akibat bersaing dalam pemanfaatan sarana tumbuh, (2) menurunkan mutu hasil akibat kontaminasi dengan bagian-bagian gulma, (3) mengeluarkan senyawa alelopati yang dapat menghambat pertumbuhan tanaman, (4) menjadi inang bagi hama dan pathogen yang menyerang tanaman, dan 5) meningkatkan biaya usahatani akibat penyiangan.

Beberapa penelitian melaporkan bahwa biomasa tumbuhan seperti jerami padi, serasah tumbuhan, termasuk alang-alang potensial digunakan sebagai mulsa (Fahrurrozi et. al., 2005, Sumarni et. al., 2006, Mayun, 2007). Namun penelitian mengenai penggunaan mulsa alang-alang untuk tanaman jagung baik cara aplikasi, waktu aplikasi maupun dosisnya belum banyak dilakukan. Oleh karena itu, perlu dilakukan penelitian untuk mengetahui sejauhmana pengaruh penggunaan mulsa alang-alang terhadap pertumbuhan dan produksi jagung, serta pengaruhnya terhadap gulma. Penelitian ini betujuan untuk mengetahui pengaruh mulsa alang-alang terhadap pertumbuhan dan produksi jagung serta pengaruhnya terhadap pertumbuhan gulma.

\section{BAHAN DAN METODE}

Penelitian ini dilaksanakan di lahan kebun percobaan Cikabayan IPB, Darmaga, Bogor dengan ketinggian tempat $250 \mathrm{~m}$ dpl, jenis tanah latosol. Penelitian ini dilaksanakan mulai bulan Januari sampai Juni 2010.

Bahan yang digunakan dalam penelitian ini terdiri dari benih jagng hibrida, pupuk kandang, pupuk anorganik seperti Urea, SP-18 dan $\mathrm{KCl}$, mulsa alang-alang, dan insektisida berbahan aktif Carbofuran. Alat-alat yang digunakan terdiri dari meteran, kuadrat, timbangan, timbangan analitik, dan alat-alat pertanian yang biasa digunakan.

Percobaan ini dilakukan dengan menggunakan Rancangan Kelompok Lengkap Teracak (RKLT) satu faktor yaitu dosis mulsa alang-alang (M) yang diulang 3 kali dengan 4 taraf perlakuan, yaitu (M1) 2 ton/ha, (M2) 4 ton/ha, (M3) 6 ton/ha dan (M4) 8 tan/ha. Selain itu, digunakan dua kontrol yaitu 0 ton/ha dengan disiangi gulmanya (K1) dan 0 ton/ha tanpa disiangi gulmanya (K2).

Tanah diolah terlebih dahulu sampai pada kondisi siap tanam, lalu dibuat petakan-petakan berukuran $6 \mathrm{~m} \times 3,5 \mathrm{~m}$ dengan jarak antar petak $50 \mathrm{~cm}$. setiap petakan diberi pupuk kandang dengan dosis 9 ton/ha. Selanjutnya tanah dibiarkan selama satu minggu untuk kemudian ditanami.

Lubang tanam dibuat dnegan tugal dengan jarak tanam $80 \mathrm{~cm} \times 40 \mathrm{~cm}$. Baisan lubanng dibuat dengan arah Utara-Selatan. Setiap lubang diisi dengan satu benih jagung dan Carbofuran lalu lubang ditutup dengan tanah. Setelah itu diberi pupuk dasar dengan secara melingkar di sekitar lubang tanam. Pupuk yang diberikan merupakan campuran dari Urea, SP-18 dan KCl dengan perbandingan yaitu $250 \mathrm{~kg} / \mathrm{ha:} 250 \mathrm{~kg} / \mathrm{ha}: 150 \mathrm{~kg} / \mathrm{ha}$. Untuk pupuk Urea diberikan secara bertahap yaitu $1 / 2$ dosis pada saat tanam dan $1 / 2$ lagi pada 4 Minggu Setelah Tanam (MST).

Mulsa diberikan pada saat selesai penanaman. Mulsa dihamparkan di lahan secara merata menutupi arela pertanaman dan dibiarkan terbuka pada bagian lubang tanam (diameter $20 \mathrm{~cm}$ ). Pemberian mulsa sesuai dengan rancangan percobaan yang telah dibuat. Petak yang sudah diberi mulsa lalu diberi label sesuai dengan perlakuannya. Pada saat 2 MST dipilih 10 tanaman contoh pada setiap perlakuan.

Pemeliharaan yang dilakukan meliputi penyulaman, penyiangan gulma serta pengendalian hama dan penyakit. Penyulaman dilakukan pada 1 MST yaitu dengan 
mengganti benih yang tidak tumbuh atau kecambah yang tidak normal dengan benih yang baru. Penyiangan gulma dilakukan dengan membersihkan semua gulma hanya pada petakan kontrol yang disiangi. Pengendalian hama dan penyakit dilakukan dengan cara teknis yaitu dengan mencabut tanaman yang terserang penyakit.

Pengamatan dilakukan terhadap 10 tanaman contoh meliputi : tinggi tanaman, jumlah daun, bobot kering tongkol berkelobot per tanaman, bobot kering tongkol tanpa kelobot per tanaman, bobot kering pipilan per tanaman dan bobot 100 buttir. Data dianalisis dengan menggunakan analisis ragam (Uji-F). Jika hasil Uji-F menunjukkan pengeruh nyata, maka untuk mengetahui perbedaan antar perlakuan dilakukan uji lanjut DMRT pada taraf $5 \%$.

\section{HASIL PEMBAHASAN}

\section{Tinggi Tanaman}

Hasil analisis ragam menunjukkan bahwa perlakuan mulsa alang-alang berpengaruh nhyata terhadap tinggi tanaman pada 7, 8 dan 9 MST, namun tidak berpengaruh nyata pada 5 dan $6 \mathrm{MST}$. Tabel 1 memperlihatkan bahwa perlakuan mulsa alang-alang 6 ton/ha dan 8 ton/ha pada 9 MST masing-masing $140.25 \mathrm{~cm}$ dan 141.03 $\mathrm{cm}$, tidak berbeda nyata dengan petak yang disiangi $(139.26 \mathrm{~cm})$, namun berbeda nayat dengan petak tanpa disiangi $(108.92 \mathrm{~cm})$. Hal ini menunjukkan bahwa penggunaan mulsa alang-alang 6 ton/ha dan 8 ton/ha akan menghasilkan tinggi tanaman jagung yang sama dengan tinggi tanaman jagung yang dibudidayakan denan penyiangan gulma.

Tabel 1. Pengaruh mulsa alang-alang terhadap tinggi tanaman jagung

\begin{tabular}{|c|c|c|c|c|c|}
\hline \multirow[t]{2}{*}{ Dosis Mulsa Alang-alang } & \multicolumn{5}{|c|}{ Umur (MST) } \\
\hline & 5 & 6 & 7 & 8 & 9 \\
\hline & \multicolumn{5}{|c|}{$\ldots \ldots \ldots \ldots \ldots \ldots \ldots(\mathrm{cm})$} \\
\hline 0 ton/ha tanpa disiangi & 64.36 & 81.73 & $99.10^{\mathrm{ab}}$ & $95.45^{a}$ & $108.92^{a}$ \\
\hline 2 ton/ha tanpa disiangi & 61.33 & 77.66 & $94.00^{\mathrm{ab}}$ & $103.33^{a b}$ & $122.61^{\mathrm{ab}}$ \\
\hline 4 ton/ha tanpa disiangi & 58.27 & 73.14 & $88.25^{a}$ & $95.00^{\mathrm{a}}$ & $113.34^{a}$ \\
\hline 6 ton/ha tanpa disiangi & 70.22 & 91.98 & $113.75^{\mathrm{ab}}$ & $120.75^{b}$ & $140.25^{b}$ \\
\hline 8 ton/ha tanpa disiangi & 72.03 & 94.68 & $117.33^{b}$ & $125.58^{b}$ & $141.03^{b}$ \\
\hline 0 ton/ha disiangi & 70.95 & 83.87 & $108.80^{a b}$ & $118.38^{a b}$ & $139.26^{b}$ \\
\hline Uji-F & tn & tn & * & * & $\overline{\star \star}$ \\
\hline \multicolumn{6}{|c|}{$\begin{array}{l}\text { Keterangan : angka pada kolom yang sama yang diikuti huruf sama, tidak berbeda nyata pada uji DMRT 50 } \\
\text { tn } \quad: \text { tidak nyata } \\
\text { * } \quad \text { berbeda nyata } \\
\text { ** berbeda sangat nyata } \\
\text { (Tabel berikutnya yang memiliki tanda tn, * dan ** mempunyai keterangan yang sama) }\end{array}$} \\
\hline
\end{tabular}

\section{Jumlah Daun}

Hasil analisis ragam menunjukkan bahwa perlakuan mulsa alang-alang berpengaruh nyata terhadap jumlah daun pada 7 dan $8 \mathrm{MST}$, namun tidak berpengaruh nyata pada 5, 6 dn 9 MST. Tabel 2 menunjukkan pada 8 MST perlakuan mulsa alangalang 6 ton/ha dan 8 ton/ha jumlah daun (9.84 helai). Hal ini menunjukkan bahwa perlakuan mulsa alang-alang 6 ton/ha dan 8 ton/ha akan memperoleh jumlah daun tanaman jagung yang sama dengan yang dibudidayakan secara biasa dengan penyiangan. 
Tabel 2. Pengaruh mulsa alang-alang terhadap jumlah daun tanaman jagung

\begin{tabular}{|c|c|c|c|c|c|}
\hline \multirow[t]{2}{*}{ Dosis Mulsa Alang-alang } & \multicolumn{5}{|c|}{ Umur (MST) } \\
\hline & 5 & 6 & 7 & 8 & 9 \\
\hline & & & elai & & \\
\hline 0 ton/ha tanpa disiangi & 6.13 & 7.05 & $7.72^{\mathrm{ab}}$ & $8.65^{\mathrm{a}}$ & 9.92 \\
\hline 2 ton/ha tanpa disiangi & 6.35 & 6.90 & $7.89^{a b}$ & $8.34^{a}$ & 10.01 \\
\hline 4 ton/ha tanpa disiangi & 6.66 & 7.10 & $7.21^{\mathrm{a}}$ & $8.45^{\mathrm{a}}$ & 9.56 \\
\hline 6 ton/ha tanpa disiangi & 7.22 & 8.00 & $8.47^{\mathrm{ab}}$ & $9.83^{b}$ & 10.55 \\
\hline 8 ton/ha tanpa disiangi & 7.30 & 8.14 & $8.90^{\mathrm{b}}$ & $10.13^{b}$ & 10.82 \\
\hline 0 ton/ha disiangi & 7.07 & 7.95 & $8.57^{\mathrm{b}}$ & $9.84^{b}$ & 10.54 \\
\hline Uji-F & tn & tn & * & * & tn \\
\hline
\end{tabular}

Produksi Jagung

Hasil penelitian ini menunjukkan bahwa perlakuan mulsa alang-alang berengaruh nyata terhadap bobot kering tongkol dengan kelobot, bobot kering tongkol tanpa kelobot dan bbobot pipilan jagung. Perlakuan mulsa alang-alang 6 ton/ha dan 8 ton/ha menghasilkan bobot kering dengan kelobot masing-masing $84.7 \mathrm{~g}$ dan $86.1 \mathrm{~g}$ tidak berbeda nyata dengan kontrol gulmanya disiangi (84.47 g), namun berbeda nyata dengan kontrol yang tidak disiangi $(53.28 \mathrm{~g})$. Perlakuan mulsa alang-alang 6 ton/ha dan 8 ton/ha menghasilkan bobot kering tanpa kelobot masing-masing $67.94 \mathrm{~g}$ dan 66.25 tidak berbeda nyata dengan kontrol yang gulmanya disiangi $(64.67 \mathrm{~g}$ ), namun berbeda nyata dengan kontrol yang tidak disiangi $(44.57 \mathrm{~g})$. Begitu juga dengan bobot pipilan (54.68 g dan $53.47 \mathrm{~g}$ ) yang tidak berbeda nyata dengan kontrol yang gulmanya disiangi $(51.30 \mathrm{~g})$, namun berbeda nyata dengan kontrol yang tidak disiangi $(35.85 \mathrm{~g})$. Pada bobot 100 butir perlakuan mulsa alang-alang tidak berpengaruh nyata (Tabel 3 ).

Tabel 3. Pengaruh perlakuan mulsa alang-alang terhadap komponen produksi jagung

\begin{tabular}{|c|c|c|c|c|}
\hline Dosis Mulsa Alang-alang & $\begin{array}{l}\text { Bobot tongkol } \\
\text { dengan } \\
\text { klobot }\end{array}$ & $\begin{array}{l}\text { Bobot } \\
\text { tongkol } \\
\text { tanpa } \\
\text { klobot }\end{array}$ & $\begin{array}{l}\text { Bobot pipilan } \\
\text { per tanaman }\end{array}$ & $\begin{array}{l}\text { Bobot } 100 \\
\text { butir }\end{array}$ \\
\hline & \multicolumn{4}{|c|}{......... (g/tanaman) } \\
\hline 0 ton/ha tanpa disiangi & $53.28^{a}$ & $44.57^{a}$ & $35.85^{\mathrm{a}}$ & 17.83 \\
\hline 2 ton/ha tanpa disiangi & $67.60^{\mathrm{ab}}$ & $55.00^{\mathrm{ab}}$ & $42.48^{\mathrm{abc}}$ & 20.06 \\
\hline 4 ton/ha tanpa disiangi & $57.84^{\mathrm{a}}$ & $48.26^{a}$ & $38.59^{\mathrm{ab}}$ & 19.04 \\
\hline 6 ton/ha tanpa disiangi & $84.57^{b}$ & $67.94^{\mathrm{b}}$ & $54.68^{c}$ & 19.33 \\
\hline 8 ton/ha tanpa disiangi & $86.10^{\mathrm{b}}$ & $66.25^{\mathrm{b}}$ & $53.47^{c}$ & 20.52 \\
\hline 0 ton/ha disiangi & $84.47^{b}$ & $64.67^{\mathrm{b}}$ & $51.30^{\mathrm{bc}}$ & 19.36 \\
\hline Uji-F & ** & * & * & tn \\
\hline
\end{tabular}

\section{Dominansi Gulma}

Berdasarkan hasil analisis vegetasi, diketahui bahwa gulma yang mendominasi di hamper semua petak percobaan yaitu gulma Borreia alata dan Axonopus compressus. Tabel 4 mennunjukkan petak yang memiliki Nilai Jumlah Dominansi (NJD) Borreia alata tinggi, memiliki NJD gulma golongan rumput yang kecil. Berdasarkan Tabel 4 dominansi Borreia alata diduga dapat menekan pertumbuhan gulma lain khususnya gulma golongan rumput. 
Tabel 4. Nilai jumlah dominansi gulma

\begin{tabular}{|c|c|c|c|c|c|c|}
\hline \multirow[t]{2}{*}{ Jenis Gulma } & M1 & M2 & M3 & M4 & K1 & K2 \\
\hline & \multicolumn{6}{|c|}{ …........... (\%) } \\
\hline Axonopus compressus (Sw.) & 13.19 & 12.82 & 8.27 & 14.21 & 74.69 & 18.14 \\
\hline Borreria alata (Aubl) DC. & 48.01 & 49.76 & 49.82 & 26.56 & 0 & 40.43 \\
\hline Sida acuta Burm. F. & 13.55 & 15.43 & 0 & 0 & 0 & 7.05 \\
\hline $\begin{array}{l}\text { Calopogonium mucunoides } \\
\text { Desv. }\end{array}$ & 12.98 & 0 & 0 & 8.43 & 0 & 8.66 \\
\hline $\begin{array}{l}\text { Otochloa nodosa (Kunth) } \\
\text { Dandy }\end{array}$ & 0 & 0 & 18.09 & 0 & 0 & 0 \\
\hline $\begin{array}{l}\text { Digitaria adscendens (Kunth) } \\
\text { Herard }\end{array}$ & 0 & 10.16 & 15.78 & 25.15 & 11.49 & 15.78 \\
\hline Cleome rutidosperma D. C. & 0 & 0 & 0 & 9.94 & 0 & 0 \\
\hline Gulma lain & 11.94 & 11.83 & 8.04 & 15.71 & 13.82 & 9.94 \\
\hline
\end{tabular}

\section{Bobot Kering Gulma}

Berdasarkan analisis ragam perlakuan mulsa berpengaruh nyata terhadap bobot kering gulma. Perlakuan mulsa alang-alang 6 ton/ha dan 8 ton/ha nyata menurunkan bobot kering gulma menjadi $29.64 \mathrm{~g} / 0.25 \mathrm{~m}^{2}$ dan $27.02 \mathrm{~g} / 0.25 \mathrm{~m}^{2}$ dibandingkan dengan kontrol yang tidak disiangi $\left(44.12 \mathrm{~g} / 0.25 \mathrm{~m}^{2}\right)$ (Tabel 5)

\section{Pembahasan}

Perlakuan mulsa alang-alang dapat meningkatkan pertumbuhan tanaman. Hal ini dapat dilihat dari tinggi tanaman dan jumlah daun yang diberikan perlakuan mulsa alangalang 6 ton/ha dan 8 ton/ha, menunjukkan hasil yang tidak berbeda nyata dengan kontrol yang gulmanya tidak disiangi (Tabel 1 dan 2). Hal ini karena penggunaan mulsa alangalang dapat menekan pertumbuhan gulma (Tabel 5). Penekanan pertumbuhan gulma dapat mengurangi kompetisi yang terjadi antara tanaman jagung dengan gulma. Berkurangnya kompetisi antara tanaman jagung dengan gulma membuat tanaman jagung dapat memanfaatkan faktor tumbuh dengan lebih baik. Hal inilah yang diduga menyebabkan penggunaan mulsa alang-alang dapat meningkatkan pertumbuhan tanaman jagung.

Tabel 5. Pengaruh mulsa alang-alang terhadap bobot kering gulma

\begin{tabular}{lc}
\hline \multicolumn{1}{c}{ Dosis Mulsa Alang-alang } & Bobot Kering Gulma $\left(\mathrm{g} / 0.25 \mathrm{~m}^{2}\right)$ \\
\hline 0 ton/ha tanpa disiangi & $44.12^{\mathrm{a}}$ \\
2 ton/ha tanpa disiangi & $40.25^{\mathrm{ab}}$ \\
4 ton/ha tanpa disiangi & $42.30^{\mathrm{ab}}$ \\
6 ton/ha tanpa disiangi & $29.64^{\mathrm{bc}}$ \\
s ton/ha tanpa disiangi $^{\text {o ton/ha disiangi }}$ & $27.02^{\mathrm{c}}$ \\
\hline Uji-F & $3.15^{\mathrm{d}}$ \\
\hline Keterangan : angka pada kolom yang sama yang diikuti huruf sama, tidak berbeda nyata pada uji DMRT 5\%
\end{tabular}

Penekanan gulma oleh mulsa alang-alang dapat dilihat dari bobot kering gulma pada setiap petak perlakuan. Penggunaan mulsa alang-alang 6 ton/ha dan 8 ton/ha dapat mengurangi bobot kering gulma dibandingkan dengan kontrol yang gulmanya tidak disiangi (Tabel 5). Hal ini diduga karena pertumbuhan gulma tertekan oleh adanya mulsa alang-alang. Mulsa alang-alang dapat menekan pertumbuhan gulma diduga karena mulsa alang-alang dapat mengurangi intensitas cahaya. Intensitas cahaya yang kurang 
diduga dapat mengurangi perkecambahan biji gulma (Sukma dan Yakup, 2002). Selain itu, mulsa alang-alang juga diduga mengeluarkan senyawa alelopati yang mempengaruhi pertumbuhan gulma. Palapa (2009) menyatakan bahwa ekstrak alang-alang dapat menghambat pertumbuhan gulma bayam duri (amaranthus spinosus).

Pada petak kontrol yang tidak disiangi, petak dengan mulsa alang-alang 2 ton/ha, 4 ton/ha dan 6 ton/ha diketahui bahwa gulma yang mendominasi jenis Borreia alata. Hal ini diduga karena Borreia alata dapat menekan pertumbuhan gulma lain karena kompetisi dan kemungkinan adanya alelopati. Penelitian Wiroatmodjo et. al., (1993) menunkukkan bahwa semakin lama keberadaan dan semakin besar kerapatan gulma Borreia alata maka komponen produksi dan produksi padi gogo semakin tereduksi. Hal ini diduga karena alelopati yang ada pada Borreia alata. Sedangkan pada petak 8 ton/ha dominasi gulma Borreia alata tidak terlalu besar tapi dominasi gulma golongan rumput (Digitaria adscendens) meningkat. Hal ini diduga karena mulsa alang-alang dengan dosis 8 ton/ha dapat menekan pertumbuhan Borreia alata.

Peningkatan pertumbuhan juga berkaitan dengan kemampuan mulsa yang dapat memperbaiki sifat fisik dan kimia tanah. Berdasarkan hasil analisis tanah akhir diketahui bahwa ketersediaan unsure makro seperti $\mathrm{N}$ total, $\mathrm{P}$ dan $\mathrm{K}$ tersedia pada petak yang diberi perlakuan mulsa alang-alang lebih besar dibandingkan dengan petak dengan perlakuan tanpa mulsa. Pada analisis tanah settelah panen unsure hara $\mathrm{N}$ total, $\mathrm{P}$ dan $\mathrm{K}$ tersedia dan yang terbesar terjadi pada perlakuan 6 ton/ha $(0.17 \%, 16.7 \mathrm{ppm}$ dan 31 $\mathrm{ppm})$ dan 8 ton/ha $(0.19 \%, 14.2 \mathrm{ppm}$ dan $30 \mathrm{ppm})$ sedangkan pada petak yang tanpa perlakuan mulsa yang disiangi $(0.15 \%, 9.1 \mathrm{ppm}$ dan $17 \mathrm{ppm})$. Hal ini sesuai dengan penelitian Fahrurrozi et. al. (2005), Umboh (2000) dan Sudadi (2007) yang menyatakan bahwa mulsa dapat menjaga kestabilan agregat dan kimia tanah, menjaga ketersediaan air tanah dan menjaga suhu tanah meningkatkan ketersediaan unsur $\mathrm{K}$ dalam tanah, dan mencegah pencucian nitrogen.

Perlakuan mulsa alang-alang dapat meningkatkan produksi jagung. Perlakuan mulsa alang-alang 6 ton/ha dan 8 ton/ha menghasilkan bobot tongkol dengan kelobot, bobot tongkol tanpa kelobot dan bobot pipilan yang tidak berbeda nyata dengan kontrol yang disiangi, namun berbeda nyata dengan control yang tidak disiangi (Tabel 3). Seperti diuraikan di atas pengeruh mulsa dapat menekan gulma serta memperbaiki sifat fisik dan kimia tanah sehingga pertumbuhan jagung menjadi lebih baik. Kondisi linkungan tumbuh yang baik dan pertumbuhan vegetatif yang baik berpeluang untuk meningkatkan produksi jagung dengan baik.

Tabel 6. Hasil analisis tanah setelah panen

\begin{tabular}{lrrrrrr}
\hline \multicolumn{1}{c}{ Sifat tanah } & \multicolumn{7}{c}{ Perlakuan } \\
\cline { 2 - 7 } & \multicolumn{1}{c}{ K1 } & \multicolumn{1}{c}{ K2 } & \multicolumn{1}{c}{ M2 } & \multicolumn{1}{c}{ M3 } & \multicolumn{1}{c}{ M4 } \\
\hline $\mathrm{pH}\left(\mathrm{H}_{2} \mathrm{O}\right)$ & 4.3 & 4.3 & 4.3 & 4.4 & 4.4 & 4.5 \\
$\mathrm{C}(\%)$ & 1.82 & 1.89 & 2.53 & 1.92 & 1.89 & 2.10 \\
$\mathrm{~N}(\%)$ & 0.15 & 0.15 & 0.21 & 0.17 & 0.17 & 0.19 \\
$\mathrm{C} / \mathrm{N}$ & 12 & 13 & 12 & 11 & 11 & 11 \\
$\mathrm{P} 2 \mathrm{O} 5$ Bray 1 $(\mathrm{ppm})$ & 9.1 & 7.5 & 23.1 & 14.7 & 16.7 & 14.2 \\
K2O Morgan $(\mathrm{ppm})$ & 17 & 19 & 23 & 17 & 31 & 30 \\
\hline
\end{tabular}

Berdasarkan pertimbangan biaya produksi, maka perlakuan mulsa alang-alang terbaik pada 6 ton/ha. Hal ini dikarenakan dengan menggunakan dosis 6 ton/ha mulsa alang-alang, pertumbuhan dan produksi jagung tidak berbeda nyata dengan dosis 8 ton/ha dan petak yang gulmanya disiangi. Penggunaan dosis mulsa alang-alang 6 ton/ha 
biaya produksinya akan lebih rendah dibandingkan dengan penggunaan dosis mulsa alang-alang 8 ton/ha.

Berdasarkan Tabel 5 diketahui bahwa bobot kering gulma perlakuan control yang gulmanya disiangi nyata lebih sedikit disbanding dengan perlakuan mulsa 6 ton/ha dan 8 ton/ha lebih baik dibandingkan dengan control yang gulmanya disiangi. Hal tersebut menunjukkan produksi jagung tidak hanya ditentukan oleh keberadaan gulma atau satu factor lingkungan saja.

\section{SIMPULAN}

Mulsa alang-alang dapat menekan pertumbuhan gulma serta meningkatkan pertumbuhan dan produksi jagung. Dosis mulsa alang-alang yang terbaik adalah 6 ton/ha biomassa alang-alang kering.

\section{DAFTAR PUSTAKA}

As-syakur, R.A. 2007. Konservasi Tanah dan Air di Lahan Kering. http://mbojo.wordpress.com/2007/07/03/konservasi-tanah-dan -air-dilahankering/. [12 April 2009]

Deparetemen Pertanian. 2009. Prima Tani Lahan Kering Dataran Rendah Iklim Basah di Jawa Barat. http://jabar.litbang.deptan.go.id/index2.php [1 Mei 2009]

2011. Data Produksi dan Produktivitas Jagung Nasional Tahun 20002009. http://database.deptan.go.id/bdsp/hasil kom.asp [24 November 2011]

Fahrurrozi, B. Hermawn dan Latifah. 2005. Pertumbuhan dan Hasil Kedelai pada Berbagai Dosis Mulsa alang-alang dan Pengolahan Tanah. Jurnal Akta Agrosia $8(1): 21-24$.

Mayun, I. D. 2007. Efek Mulsa Jerami Padi dan Pupuk Kandang Sapi terhadap Pertumbuhan dan Hasil Bawang Merah di Daerah Pesisir. Agritrop, 26 (1) : 3340.

Palapa, T. M. 2009. Senyawa Alelopati Teki (Cyperus rotundus) dan Alang-alang (Imperata cylindrical) Sebagai Penghambat Pertumbuhan Bayam Duri (Amaranthus spinosus). Agritek 17 (6): 1155-1162.

Sudadi, Y., N. hidayati, dan Sumarni. 2007. Ketersediaan K dan hasil kedelai (Glycine max L. Merril) pada Tanah Vertisol yang Diberi Mulsa dan Pupuk Kandang. Jurnal Ilmu Tanah dan Lingkungan 7(1): 8-12.

Sukman, Y. dan Yakup. 2002. Gulma \& Teknik Pengendaliannya. PT. Raja Grafindo Persada. Jakarta. 160 hal.

Sumarni, N., A. Hidayat, dan E. Sumiati. 2006. Pengaruh Tanaman Penutup Tanah dan Mulsa Organik Terhadap Produksi Cabai dan Erosi Tanah. J. Hort. 16(3):197201.

Umboh, A. H. 2000. Petunjuk Penggunaan Mulsa. Penebar Swadaya. Jakarta. 88 hal.

Wiroatmodjo, J., I. H. Utomo, R. Daos dan Warma. 1993. Studi alelopati Borrieria alata Terhadap Pertumbuhan dan Produksi Tanaman Kedelai dan Padi Gogo. Buletin Agronomi 21(2):39-49. 